\title{
スギ材をメタルプレートコネクターで接合した継手の強度特性
}

林 知 行* 軽 部 正彦**
原 田 真 樹* 井道 裕 史

\section{Strength Properties of Sugi Timber-Joints with Metal Plate Connectors}

\author{
by \\ Tomoyuki HaYashi ${ }^{*}$, Masahiko Karube ${ }^{*}$, Masaki HaradA ${ }^{*}$ and Hirofumi Ido ${ }^{* *}$
}

\begin{abstract}
Gusset truss systems using metal plate connectors have been developed and used in residential constructions in Japan. Several softwoods, such as SPF (Picea spp., Pinus spp., and Abies spp.) and White Spruce (Picea abies Karst), have been used as structural members of the systems. However, Sugi (Cryptomeria japonica D. Don), the most important species in Japan has not been used so far.

To examine the feasibility of Sugi, tensile strength tests were made on Sugi timber joints with two kinds of metal plate connectors (GN80 and GNQ). Furthermore, full size bending tests of roof trusses composed of Sugi and GN80 were conducted to discuss the availability of current structural design method.

Sugi joints showed lower maximum strength and toughness than SPF and White Spruce. However, it was found that Sugi had enough performance required for structural members. Coefficient of correlation between the density of wood and tensile strength of the joint was positive in any kinds of specimens, but most of them were less than 0.3. The current design method for plate size and truss members can be applied to the Sugi gusset trusses, though its estimation for deformation is rather conservative.

Since the mechanical properties of Sugi vary with its cultivar, provenance, or other factors, such as the amounts of small knots, more experimental data should be accumulated to expand the practical applications.
\end{abstract}

Key words : Metal plate connector, Timber joint, Metal plate gusset truss, Sugi, Full size test

\section{1 緒言}

わが国にメタルプレートコネクター (MPC) を用いた ガセットトラスシステムが登場したのは, 枠組壁工法の 導入を前にした 1973 年であった。当時, MPC はわが国 に扔いて全く新しい製品であったために，穴の強度特性 に関する基礎的なデータは皆無であった。このため, 各

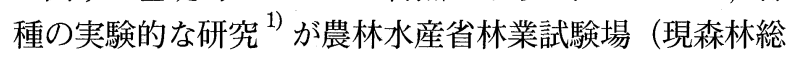
合研究所）を中心に行われた。

その後, 各地の研究機関や大学で, 実大屋根トラスの 変形挙動, ${ }^{2}$ 引張クリープ特性, ${ }^{3}$, 繰返し荷重における変形 特性, 年, 疲労特性, 年, 時間依存性, ${ }^{6}$, 試験体形状と強度特性

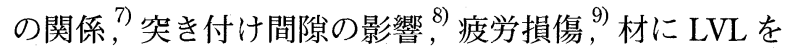
用いた場合の強度特性 ${ }^{10)}$ などに関する研究が積極的に行 われた。この結果, MPC は構造用金物として広く認知 されることとなった。

ただ逆に, MPC に関する研究は, 1980 年代の半ば以 降，低調となった。わずかに，新開発されたステンレス 製 MPC を用いた平行弦トラス ${ }^{11)}$ および屋根トラスの曲 げ挙動, ${ }^{12)}$ 各種 LVL の適用性試験, ${ }^{13)}$ 部材剛性の影響, ${ }^{14)}$ はしご梁の強度特性 ${ }^{15)}$ などに関する研究が散発的に行わ れてきただけであった。

このように, 研究面では停滞状況にあった MPCでは あるが，近年資源が充実しつつあるスギ (Cryptomeria japonica D. Don) の需要拡大の一方策として，MPC を用
いた組み立て部材の利用 ${ }^{16)}$ や畜舎への応用などが注目さ れるようになってきた。

しかしながら，スギを MPCで接合した継手について は，基礎的なデータがほとんど存在せず，また，スギの ガセットトラスは未だ公的な認定が得られていない。こ れはガセットトラスの主な需要先が枠組壁工法であり, ディメンジョンランバーとしての用途がないスギは，原 材料として対象にならなかったためである.

このような情勢を背景に, 本研究では MPC を用いた スギトラスの実用化を目的として, スギ材の継手の引張 試験を行い，只の基礎的な強度特性を検討した。 また， 3 体ではあるが実大の屋根トラスの曲げ試験を行い, 部材 のたわみや接合部の変形などについても検討した。 なお， 継手の試験に扔いては, 対照材として北米産の SPF (Spruce-Pine-Fir : Picea spp., Pinus spp., and Abies spp.), 北 欧産ホワイトスプルース (White Spruce: Picea abies Karst)についても同数の試験を行った。

\section{2 試}

\section{$2 \cdot 1$ 供試体}

. 継手の引張試験に用いたスギは宮城県の登米森林組合 に伐採から製材までを依頼したものである，材は厚さ50 $\times$ 幅 $105 \mathrm{~mm} \times$ 長さ $1 \mathrm{~m}$ 弱に粗挽きした後，含水率 $10 \%$ を目標に熱風減圧乾燥し，さらに断面を厚さ $45 \times$ 幅 $90 \mathrm{~mm}$ に仕上げた。材料の断面を一般的な $2 \times 4$ ディメ

$\dagger$ 原稿受理 平成 12 年 6 月 29 日 Received June 29,2000

* 正会員 森林総合研究所 T305-8687 茨城県稲敷郡茎崎町, Forestry and Forest Products Res. Inst., Tsukuba-gun, Ibaraki, 305-8687

** 森林総合研究所 †305-8687 茨城県稲敷郡茎崎町, Forestry and Forest Products Res. Inst., Tsukuba-gun, Ibaraki, 305-8687 
ンジョンランバー（厚さ $38 \times$ 幅 $89 \mathrm{~mm} ）$ より大きく設 定したのは，スギの密度とヤング率が低いため，トラス にした場合，対照とした 2 樹種より大きな断面が必要で あろうと考えられたからである (Table I). なお，プレ 一トを圧入する前に打撃法扎よび小荷重法により材のヤ ング係数 (MOE) を計測した．打撃法による MOEの值 は平均が $8.0 \mathrm{GPa}$, 変動係数が $12 \%$ であった. 小荷重法 によるそれは平均が $7.9 \mathrm{GPa}$ ，変動係数が $13 \%$ であった。

対照材として用いたSPF 打よびホワイトスプルースは， 関東ギャングネイル社がトラス製品に用いている一般的 な $2 \times 4$ ディメンジョンランバーの乾燥材で, JAS 製材 品の甲種 2 級相当の目視検査が施されたものである. 極 端に密度の低いものや高いものは予めロットから除外さ れていたため, Table I からも明らかなように変動係数 は非常に低い值を示した。なお，いずれの樹種も含水率 は $10 〜 12 \%$ の範囲内にあった.

用いた MPC はギャングネイル社製の GN80 および GNQの 2 種類 (Fig. 1) である. GN80 はわが国に導入 された時期より用いられている製品である。一方，GNQ は比較的新しい製品で，プレートの厚さを薄くし，単位 面積あたりの茵数を増やしたものである。ただし，茵の 長さは GN80より短い。なお，MPCの寸法は Row の数 (Fig. 1) が増えるとプレートの中央破断が生じるため， ここでは市販品より，Row の数が少ないものを用意した (Table II ).

試験体数はスギの材質のバラツキが大きいことを考慮 して，1条件あたり 32 体とした.このため，総試験体数 は 128 体 (=コネクター 2 種類 $\times 2$ 試験方向 $\times 32$ 体 $)$ となった (Fig. 2). なお，他の 2 樹種についても同条件 で同数の試験を行った。

プレートは，木材を中央で鋸断した後，そのままの方 向で突き付け，上下方向から圧入した。なお，圧入部分 に節が入ることは避けた。 スギ以外の 2 樹種については

Table I. Density of wood.

\begin{tabular}{|c|c|c|c|}
\hline & Sugi & SPF & \multicolumn{1}{c|}{$\left(\mathrm{g} / \mathrm{cm}^{3}\right)$} \\
\hline Ave. & 0.343 & 0.496 & 0.501 \\
\hline SD & 0.0348 & 0.0134 & 0.0215 \\
\hline CV & $10.1 \%$ & $2.71 \%$ & $4.30 \%$ \\
\hline
\end{tabular}

Note: Ave. : Average, SD : Standard deviation, $\mathrm{CV}$ : Coefficient of variation.
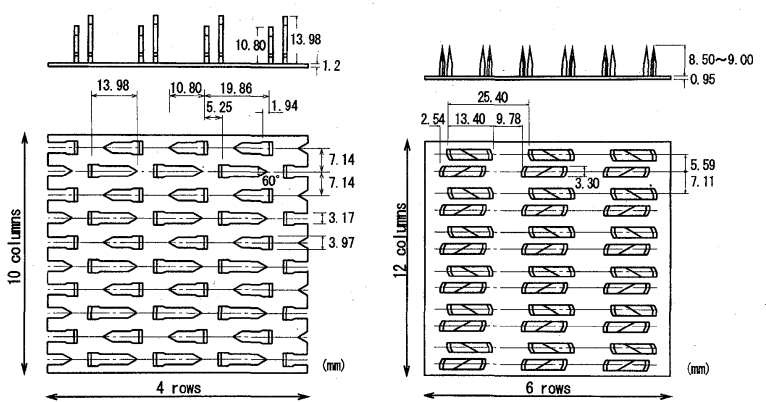

Fig. 1. Schematics of metal plate connectors. Left : GN80, Right : GNQ.
Table II . Plate size and the number of teeth.

\begin{tabular}{|c|c|c|c|}
\hline Plate & Specimen & Size (mm) & No. of teeth \\
\hline GN80 & P type & $71 \times 160$ & 40 \\
\cline { 2 - 4 } & C type & $71 \times 160$ & 40 \\
\hline \multirow{2}{*}{ GNQ } & P type & $75 \times 150$ & 72 \\
\cline { 2 - 4 } & C type & $50 \times 175$ & 56 \\
\hline
\end{tabular}
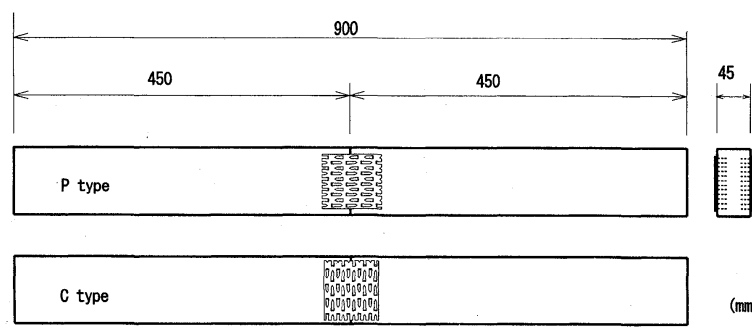

Fig. 2. Schematics of tensile test specimens. Note : $\mathrm{P}$ type : Columns of the teeth are parallel to the wood grain, $\mathrm{C}$ type : Columns of the teeth are perpendicular to the wood grain.

長さ $3.6 \mathrm{~m}$ 強の材を 4 等分し，同様の手法で上記 4 種類 の試験体を作成した。

上で述べた継手の引張試験の他に，プレートと荷重方 向の角度の影響を調べるために, Fig. 3 のように 7 種類 の角度を持った試験体を作成し，引張試験を行った。試 験に用いた樹種はスギのみで，試験体数は $15^{\circ}, 30^{\circ}, 75^{\circ}$ について各 3 体，それ以外は 2 体とした。用いたスギは 密度の影響を避けるため，平均密度がほぼ同等 $\left(0.360 \mathrm{~g} / \mathrm{cm}^{3}\right)$ でバラツキの少ない（変動係数：3.9\%) 宮崎産材（厚さ $35 \times$ 幅 $135 \times$ 長さ $700 \mathrm{~mm}$ ）を用いた. 用いた MPC は GN80で，㐘数は 90 本であった。なお， 図中に示した有効茵数は，突き付け部の上に存在する茵 数と材に圧入されなかった茵数とを, 全体の柬数から差 し引いたものである.
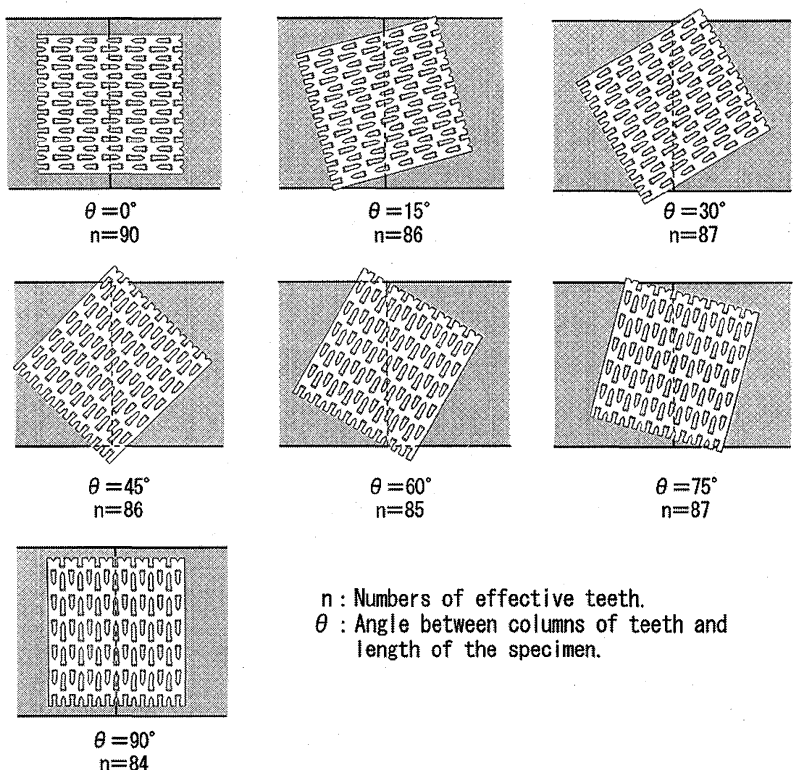

$n:$ Numbers of effective teeth.

$\theta:$ Angle between columns of teeth and length of the specimen.

Fig. 3. Schematics of test specimens composed of MPC with various plate angles. 
実大試験に用いたトラスは, Fig. 4 に示すような形態 のワーレンタイプで，材は先に示した宮城県産のスギの みとした. プレート (GN80) や部材のサイズは図中に示 したとおりで, 試験体数は 3 体とした，斜材に継手を入 れたのは，通直材よりも㛜しい条件を意困的に与えたた めである。なお，トラスの製作は関東ギャングネイル社 に依頼した。

\section{$2 \cdot 2$ 試験方法}

継手の引張試験には, 引張型プルーフローダー NET40 （容量 400kN）を用い, Fig. 5 のように試験体の両端 を硬質ゴム被覆タイプの楔形チャックで挟み込み, 破壊 に至るまで単調に加力した.

荷重の検出には試験機に組み込まれたロードセルを， また部材相互の相対変位の測定には試験体の上下に取り 付けた変位計 (Fig. 5) を用いた。

変位計およびロードセルで得られた出力信号は, デジ タルひずみ測定器を経由し, GPIB を介してパーソナル コンピューターに送られ，その後自動的に処理された。

プレートの角度の影響を検討するための実験，および トラスの実大試験後に行った非破壊接合部の引張試験 （後述）については, 試験体の寸法が異なるだけで, 試験 方法は上述したものと同様である。

トラスの実大曲げ試験は, 縦型万能試験機（容量 $200 \mathrm{kN})$ を用いて, 4 点曲げ形式の 2 点集中荷重で行っ た (Fig. 4). 加力に際しては, 面外座屈防止用の拘束冶 具を使用した.

供試体は，支点に付属する鋼製ブロック(支持鋼鈑 ) 上 に直に設置した. 加力点では, 試験体の斜材の勾配に合 わせた加力点補助ブロックをスギ角材で作製し, 供試体 と加力点ブロックとの間に挟み込んだ.

加力は，繰返しを行わずに破壊まで単調に増加させた。 供試体の各部には，あらかじめ変位計を設置し，スパン 方向全体のたわみ状況のほか, 接合部の変位, 端部支点 のめり込み等を計測した。

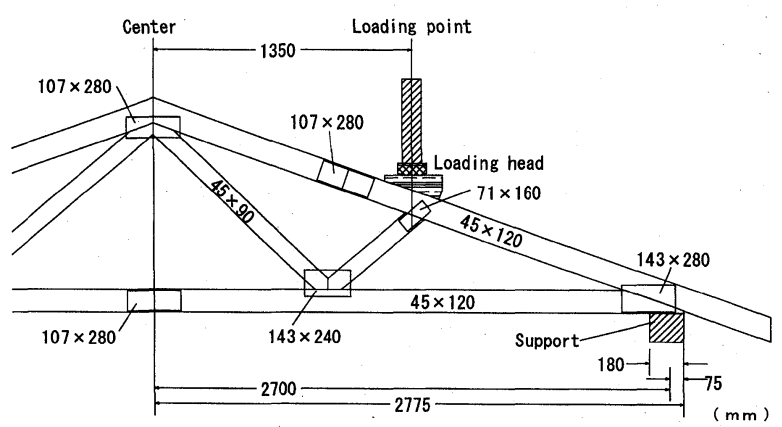

Fig. 4. Schematics of a full size truss specimen.

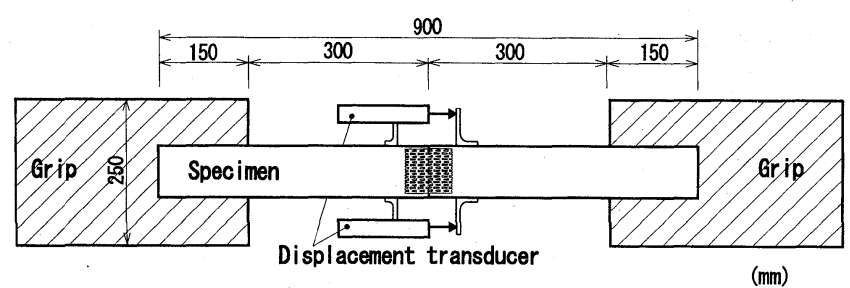

Fig. 5. Schematics of tensile test.
継手の引張試験と同様に, 変位計の歪出力と荷重計か ら得られた出力はデジタル歪測定器を経由し, GPIBを 介してパーソナルコンピューターに送られ，その後自動 的に処理された.

実大試験終了後, 破壊が生じなかった上弦材打よび下 弦材の接合部については, 部材を適当な長さに切断した のち, 継手の試験と同様の方法で，単調加力で引張試験 を行った。

\section{$3 \cdot 1$ 継手の引張試験 \\ 3 結 果 と 考 察 \\ (1) 破壊形態}

先に述べたようにプレートは Row の数が少ない形状の ものを用いたため, プレート中央の金属部の破断は生じ なかった。ほとんどの試験体で，プレートの端部から， 雨が引き抜けるとともに，プレートがめくれ上がるよう な形態で破壊が生じた。各樹種間で極端な差は見られな かったが，全般的に，スギは茵が引き抜けやすく，また 材の面圧部分をむしり取るような形態で破壊する傾向が 強かった．これは，スギの密度が低いこと，また早材晚 材の境界での強度変化が著しいことによるものと考えら れる。

荷重方向による変化としては, P タイプでは, 突き付 け部に向かって菊の先端近傍の早晚材境界がせん断破壊 する場合が多く，一方 C タイプでは，プレートのめくれ 上がりに伴って茵が抜け出すものが多かった.

なお，実大トラスの残存試験体では，Rowの数が多い プレート形状であったため，すべての試験体においてプ レートの中央破断が生じた。このため，7 体の平均值が $50.7 \mathrm{kN}$ ，その変動係数が $1.80 \%$ という非常にバラツキの 少ない結果となった。

\section{(2) 最大耐力と許容耐力}

最大耐力, 最大耐力時の変位, ならびに許容耐力を決 定する際に必要となる $0.76 \mathrm{~mm}$ 変形時の耐力 ${ }^{17)}$ を Table III に示す．なお，QP と QC では雬数が異なるので両者 の最大耐力を直接比較することには意味がない.

まず最大耐力をみると，スギは全般的にSPF の 1 割 減, ホワイトスプルースの 2 割減程度の值を示している. また, スギの変動係数は, いずれの条件においても最も 大きい值となっている。ささら， $0.76 \mathrm{~mm}$ 変形時の耐力 でも，スギは他の 2 樹種に比べて低い值を示している. これは，スギの密度が低いことに加えて，その変動係数 が $10 \%$ (他の樹種では 3 ～4\% 程度）と高かったためであ ろう.

一方, 最大耐力時の変位をみると, スギの值は NP を 除いていずれの条件でも, 他の 2 樹種と同等の值を示し ている.

試験で得られた荷重と相対変形の関係を Fig. 6 〜 8 に 示す。これらの曲線はいわゆるマスターカーブではなく, いずれも平均的な挙動を示した 1 試験体の 1 データを表 したものである。これらの罒からも明らかなように，ス ギは最大耐力が他の 2 樹種に比べて低く，また $\mathrm{P}$ タイプ では少し粘りが少ない傾向にある.

以上のように，スギは最大耐力と $0.76 \mathrm{~mm}$ 変形時の耐 力が他の 2 樹種より低く, 粘りも小さい傾向にあるが, 
Table III. Maximum load and the related values.

\begin{tabular}{|c|c|c|c|c|c|c|c|c|c|c|c|c|c|}
\hline \multirow{2}{*}{ Sugi } & \multirow[b]{2}{*}{ Specimen } & \multicolumn{4}{|c|}{ Maximum load (kN) } & \multicolumn{8}{|c|}{ Displacement at maximum load (mmLoad at $0.76 \mathrm{~mm}$ displacement $(\mathrm{kN})$} \\
\hline & & NP & NC & QP & QC & NP & NC & QP & QC & NP & NC & QP & QC \\
\hline & Ave. & 16.6 & 13.1 & 15.3 & 9.7 & 24.9 & 16.3 & 11.5 & 14.6 & 11.8 & 11.2 & 13.9 & 8.4 \\
\hline & SD & 1.97 & 1.72 & 1.79 & 1.04 & 7.25 & 2.27 & 2.19 & 2.03 & 1.09 & 1.48 & 1.51 & 1.10 \\
\hline & $\mathrm{CV}$ & $11.8 \%$ & $13.1 \%$ & $11.7 \%$ & $10.7 \%$ & $29.1 \%$ & $13.9 \%$ & $19.1 \%$ & $13.9 \%$ & $9.3 \%$ & $13.2 \%$ & $10.8 \%$ & $13.1 \%$ \\
\hline \multirow[t]{4}{*}{ SPF } & Specimen & NP & $\mathrm{NC}$ & QP & QC & NP & $\mathrm{NC}$ & $\mathrm{QP}$ & QC & NP & NC & $\mathrm{QP}$ & QC \\
\hline & Ave. & 19.6 & 15.2 & 19.6 & 10.7 & 35.5 & 14.5 & 9.5 & 11.3 & 14.2 & 13.7 & 18.8 & 10.0 \\
\hline & SD & 1.25 & 1.10 & 1.53 & 1.00 & 6.26 & 2.25 & 1.37 & 1.62 & 0.83 & 0.86 & 1.17 & 0.88 \\
\hline & $\mathrm{CV}$ & $6.4 \%$ & $7.2 \%$ & $7.8 \%$ & $9.3 \%$ & $17.6 \%$ & $15.5 \%$ & $14.4 \%$ & $14.3 \%$ & $5.9 \%$ & $6.3 \%$ & $6.2 \%$ & $8.8 \%$ \\
\hline \multirow[t]{4}{*}{ White Spruce } & Specimen & NP & NC & QP & $Q \mathbf{Q C}$ & NP & $\mathrm{NC}$ & QP & QC & NP & $\mathrm{NC}$ & QP & QC \\
\hline & Ave. & 18.6 & 14.7 & 19.2 & 10.9 & 38.7 & 16.6 & 11.4 & 12.9 & 13.3 & 12.8 & 17.8 & 10.0 \\
\hline & SD & 1.40 & 1.08 & 1.34 & 0.96 & 7.92 & 2.43 & 1.79 & 1.76 & 0.86 & 0.85 & 0.93 & 0.89 \\
\hline & $\mathrm{CV}$ & $7.6 \%$ & $7.3 \%$ & $7.0 \%$ & $8.8 \%$ & $20.5 \%$ & $14.6 \%$ & $15.8 \%$ & $13.6 \%$ & $6.5 \%$ & $6.7 \%$ & $5.2 \%$ & $8.9 \%$ \\
\hline
\end{tabular}

Note: $\mathrm{N}: \mathrm{GN} 80, \mathrm{Q}: \mathrm{GNQ}, \mathrm{P}:$ Columns of the teeth are parallel to the wood grain, $\mathrm{C}:$ Columns of the teeth are pependicular to the wood grain, Ave. : Average, SD : Standard diviation, $\mathrm{CV}:$ Coefficient of variation.

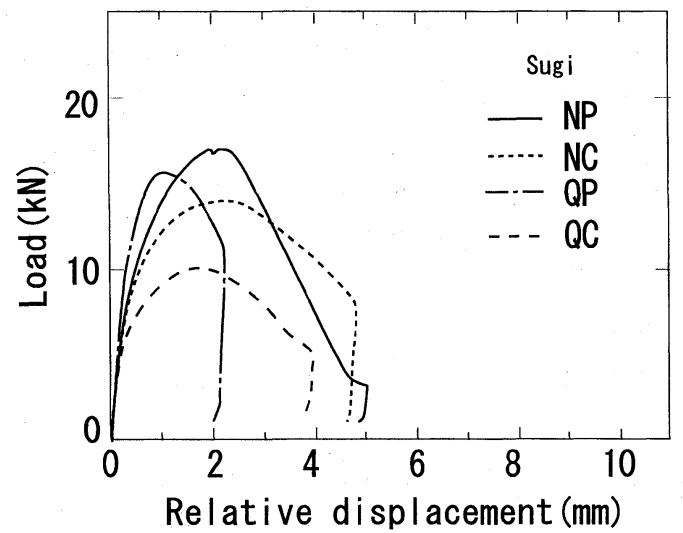

Fig. 6. Load-displacement curves of Sugi specimens.

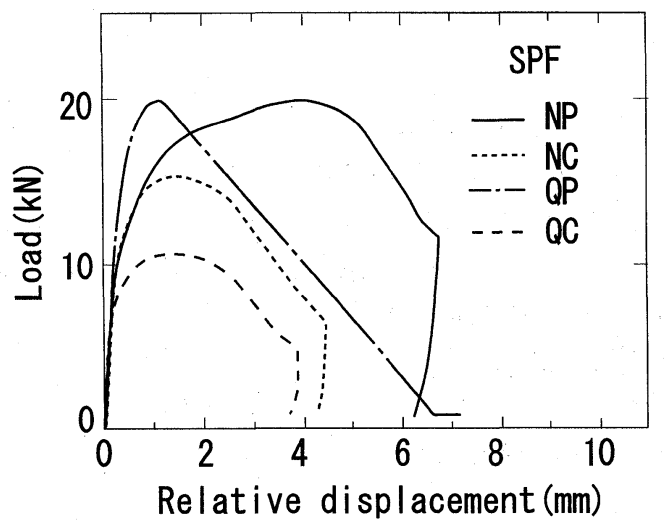

Fig. 7. Load-displacement curves of SPF specimens.

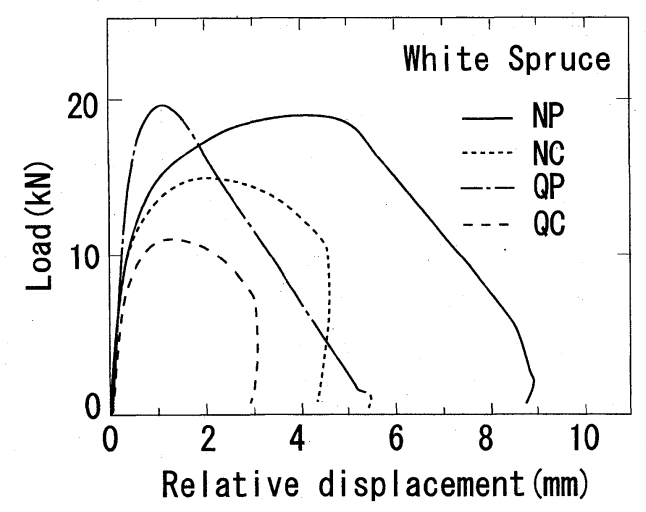

Fig. 8. Load-displacement curves of White Spruce specimens.
ガセットトラスの軸材として不都合となるような欠点は 見受けられない.

これらのことから判断して, 最大耐力と粘りの低下を 考慮して, 若干大きなプレートを用いれば，スギをガセ ットトラスの軸材に用いることは十分可能であると考え られる。ただし，スギは産地や品種によって強度特性の バラツキが大きいので，実際に様々な用途に応用するた めには，さらなる実験的データの蓄積が必要であろう.

「日本建築学会 木質構造計算基準・同解説」 ${ }^{17)}$ によ れば, MPCの短期許容耐力は, i) 最大耐力 $\left(P_{\max }\right)$ をプ レート面積で除した值に安全係数 $1 / 2$ とバラッキ調整係 数 $3 / 4$ を乗じた值 $\left(S_{3 / 8}\right)$, ii) $0.76 \mathrm{~mm}$ 変位時の荷重にバ ラツキ調整係数 $3 / 4$ を乗じた值 $\left(S_{3 / 4}\right)$ のうち, 小さい方 で与えられる。上の実験結果の場合，いずれの条件であ ってもi)の值となった。

\section{(3) プレートと荷重方向の角度の影響}

プレートと荷重方向の角度の影響を調べるために， Fig. 3 の試験体について行った試験結果を Fig. 9 に示 す. 図中には最大耐力 $\left(P_{\max }\right)$, 変位 $0.76 \mathrm{~mm}$ の耐力 $\left(P_{0.76}\right) ，\left(S_{3 / 8}\right)$ および $\left(S_{3 / 4}\right)$ を示した.ただし, 耐力は すべて有効柬一本あたりの值に換算したものである.

図から明らかなように，角度が大きくなるにしたがっ て, 最大耐力 $\left(P_{\max }\right)$ は右下がりで若干上に凹の傾向を 示したが, 変位 $0.76 \mathrm{~mm}$ の耐力 $\left(P_{0.76}\right)$ は単調に右上が りとなる傾向を示した。このため, 許容耐力は $0 \sim 30^{\circ}$ までは $S_{3 / 4}$ となり， $45^{\circ}$ でそれが逆転し, $90^{\circ}$ までは $S_{3 / 8}$ となった.この結果は, いずれの条件でも $S_{3 / 4}$ が許容耐 力になった先の実験の場合と少し異なっている.

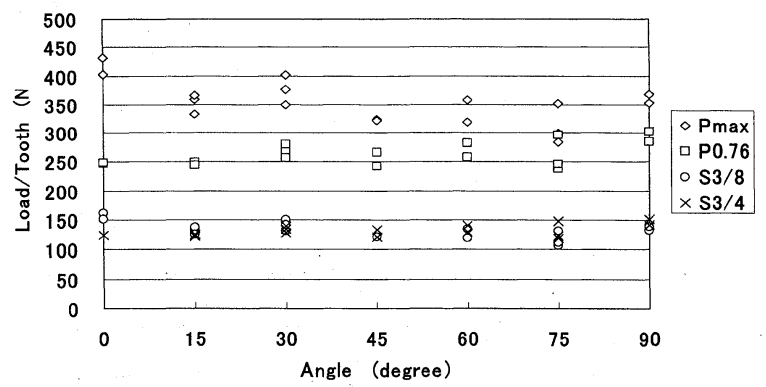

Fig. 9. Effect of plate angle on maximum load and allowable load per tooth. 
Fig. 10 は荷重と相対変位の関係をプレートの角度を パラメータとして表したものである。図から明らかなよ うに，0.76mm（接合部における便宜的な比例限度）を 越えてから最大耐力に至るまでの曲線の傾斜が，プレー 卜角度の増加に伴って緩やかになっている．言い換える と，接合部はプレート角度が小さい間は， $0.76 \mathrm{~mm}$ を超 えてもすぐに最大荷重に達しないで粘り続けるのに対し， 角度が大きくなるのに伴って，粘りが少なくなっている.

このように，MPC 継手の荷重一変形特性はプレート の形状によって若干変化するので, スギについて様々な 形状のプレートと加力の角度についての関係を調べてお くことが望まれる，ただ実際のトラスではこのような塑 性的な特性を考慮して設計する必要性はなく，また上で 導かれたような許容耐力は, Fig. 10 の荷重一変形曲線 から考えても妥当な值であると考えられる。したがって， 現行の許容耐力による設計法をスギガセットトラスに応 用しても，特に問題はないと考えられる.

\section{(4) 密度と最大耐力との相関関係}

スギ試験体に打ける密度と最大耐力 $\left(P_{\max }\right)$ との相関 図を Fig. 11 に示す.

一般に金物接合では材の密度と最大耐力との間に比較 的強い相関関係が見られることが多い. ${ }^{7}$ しかしながら本 研究の結果では，スギのみならず他の 2 樹種のいずれの 条件においても両者の相関は弱く, 相関係数が 0.3 以下 となる場合が大半であった，ただ，回帰直線の傾きが正 の值を示すものがほとんどであった.

これは, はじめに述べたように，材料選択の段階で極

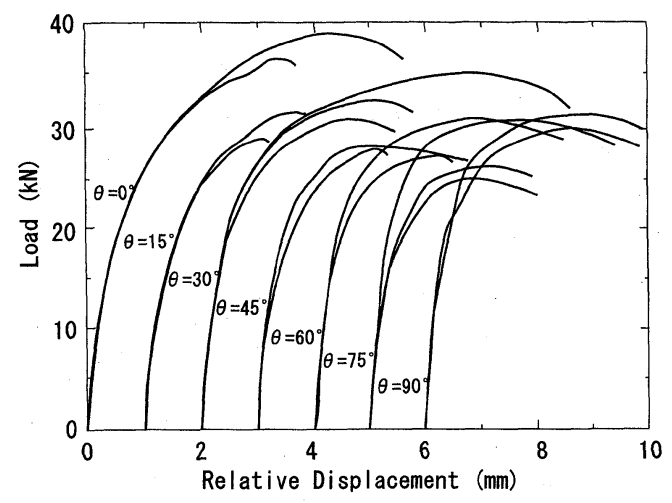

Fig. 10. Load and displacement curves of Sugi specimens with various plate angles. $\theta$ : Plate angle.

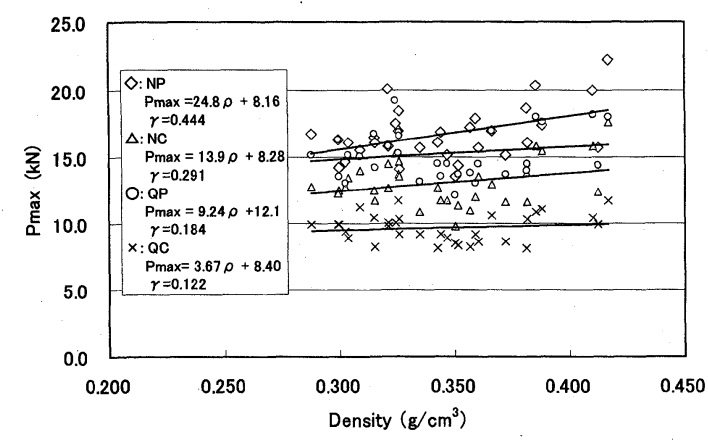

Fig. 11. Linear regression between Pmax and density of Sugi specimens. $\gamma$ : Coefficient of correlation.
端に密度の高いあるいは低いものが排除されていたため, 密度の範囲が狭くなり，その結果として相関係数が低く なったものと思われる.

なお，材の密度と同様に，材の MOE と最大耐力との 間にも強い相関は見られなかった。

\section{(5) 強度分布}

上で述べたように密度と $P_{\max }$ との間に強い相関が見ら れなかったので, ここでは密度による強度の補正を行わ ず，得られた $P_{\max }$ のデータに直接 3 パラメータワイブル 分布を当てはめた. 各試験体の確率密度分布曲線を Fig. 12 に示す.

これらの曲線からも明らかなように, QP が少し左に 裾を引いた（右に傾いた）ような分布形をしているが, 全般的にはいずれの分布も特徴的な形態ではない.

荷重抵抗係数設計法（限界状態設計法）に対応した ANSI の 1995 年版 ${ }^{18)}$ では, 継手の強度を正規分布, そ の変動係数を $14 \%$ と仮定している.この值はアメリカの 全国的なサンプリングから得られたものであるため，本 試験で得られたスギのそれ (Table III) より幾分高めの值 となっている.また, 他の 2 樹種の值の 2 倍程度となっ ている.

いずれにしても，スギの継手の強度は，対照の 2 樹種 に比べればバラツキが大きいが，極端に大きくはなく， また分布形状も特異ではない。したがって, 密度が低い ことを考慮すれば，他の樹種と同様な設計が可能である といえよう。ただし，本研究ではスギに多く見られる小 節が強度特性に及ぼす影響については検討していない. この問題については更なる検討が必要である.

\section{$3 \cdot 2$ 実大トラス試験の結果}

試験体 No.1 では，斜材接合部の頂部側プレート端部が 面外座屈により折れ，それに伴ってトラス頂部の接合部， ラチス材と斜材の接合部などで破壊が生じた (Fig. 13).

試験体 No.2 では, 支点近傍の斜材と下弦材接合部付 近に扎いて下弦材が引張破断した。 また加力点近傍で上 弦材が面内方向に折れ曲がった。

試験体 No.3では, 斜材の接合部を変曲点として, 緩 やかに面外座屈した.

全ての試験体を通して, 斜材接合部, 頂部接合部等の 圧縮力を受けるトラス接点では, 試験体製作時のわずか な隙間が, 荷重増加につれて閉じていき, 接合部のメタ ルプレートの座屈が生じた。

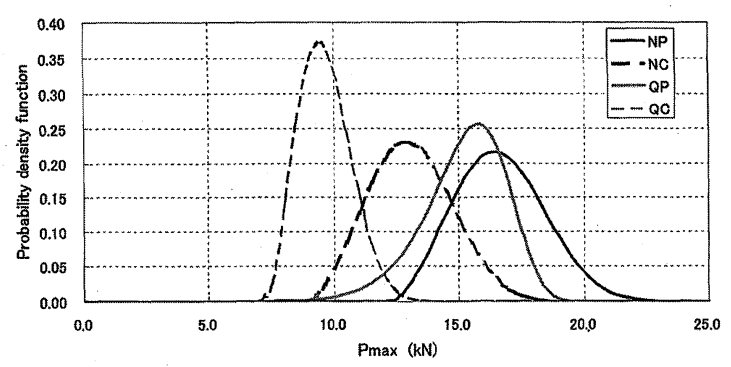

Fig. 12. Probability density function (3 parameter Weibull distribution) for maximum load of Sugi specimens. 
各試験体の最大荷重は, 加力シリンダーの值で, 35.5kN (No.1)，46.9kN (No.2)，45.7kN (No.3) であった。 この值は, スパン方向 $1 \mathrm{~m}$ あたりの長期鉛直荷重を $1.27 \mathrm{kN} / \mathrm{m}$ として計算した場合の長期荷重 $(8.24 \mathrm{kN})$ の, それぞれ 4.31 倍 (No.1)，5.69 倍 (No.2)，5.55 倍 (No.3) に相当する。ただし，この荷重条件は本試験の状態に合 わせて等分布荷重を集中荷重に置き換えたものであるた め，奉際に作用する荷重とは少し異なる。

トラスに作用させた荷重と下弦材中央部のたわ多の関 係を Fig. 14に示す。ここで, 縦軸の荷重は加力点荷重, 横軸は中央たわみからトラス尼での母材のめり込多減 じて求めた「純粋な中央たわみ」である。また，罒中の 上の直線 $\mathrm{P}-\delta(1)$ は，接合部を完全な剛節として有限要 素法により解析した計算結果である。同様に図の下の直 線 $\mathrm{P}-\delta(2)$ は接合部をピンとして解析した計算結果（一 般的なガセットトラスの構造計算方法による結果）であ る。なお，解析の際には材の曲げヤング係数を $8.0 \mathrm{GPa}$ と 仮定した。

よく知られているようにこの種のトラスの接点は半岡

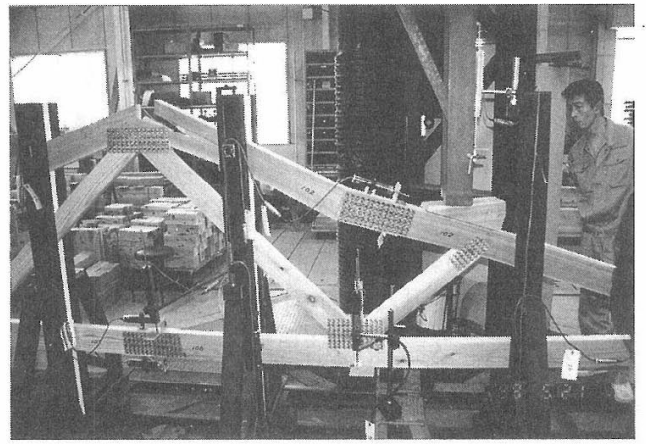

Fig. 13. Buckling failure at the joint on upper chord of a fullsize test specimen.

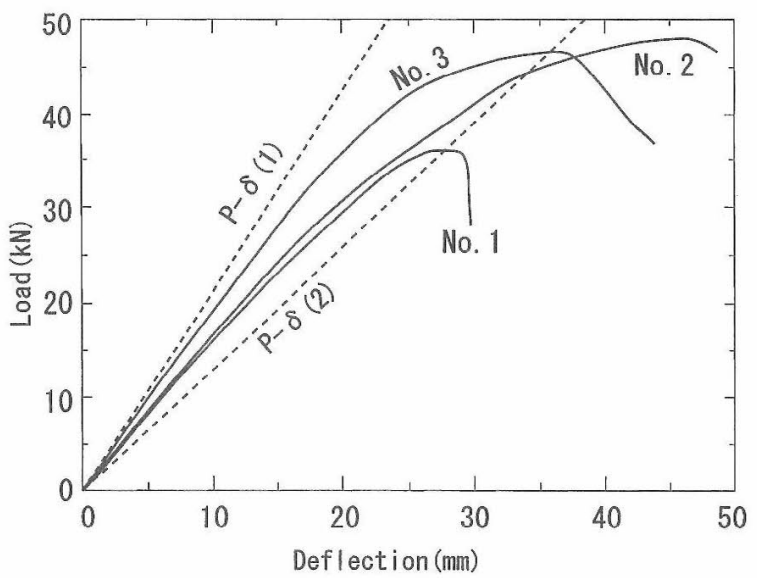

Fig. 14. Load and deflection curves at the center of lower chord.

Note : P- $\delta(1):$ Caluculated by finite element method assuming that all joints are rigid, P- $\delta(2)$ : Caluculated by finite element method assuming that all joints are pins.
節的な挙動をすることが多い。実測された荷重一たわみ 曲線が上の直線と下の直線に挟まれたところに存在する のはこのためである。一般的なガセットトラスの構造計 算方法は，幾分安全側の結果学導くことになるが，スギ ガセットトラスの設計に用いることに，問題はないと判 断される。

$$
4 \text { ま め め }
$$

メタルプレートコネタターを用いたスギ継手は, SPF やホワイトスプルースに比べて，最大耐力や粘りが若干 低いが，それを考虑すれば，スギをガセットトラスの軸 材に用いることは十分可能である。また継手やトラスに 関する現行の設計方法は只のまま応用できる。たたし， スギは産地や品種によって強度特性のバラッキが大きい ので，実際に様々な用途に応用するためには，節の影響 などを含めたさらなる実験的データの蓄積が必要である。

本研究の試験体の作成にあたり，宮城県迫農林振興事 務所の伊藤彦紀氏，登米町森林組合，関東ギャングネイ ルトラス(株)の各位にご協力いただいた。ここに厚く感謝 の意を表する。

\section{参 考 文 献}

1）金谷紀行, 材料，32，922（1983）。

2) 伊藤勝彦, 丸山武, 宮野 博, 倉田久敬, 山本宏, 工藤 修，木材学会北海道支部講演集，8，25（1976）。

3) 徳田迪夫, 竹下昌彦, 杉山圤男, 木材学会誌, 25, 399 (1979).

4) 徳田迪夫, 竹下昌彦, 杉山英男, 木材学会誌, 25, 408 (1979).

5) T. Hayashi, H. Sasaki and M. Masuda, Forest Products Journal, 30, 49 (1980).

6) 林 知行, 佐々木光, 材料, 30，697 (1981).

7) T. Hayashi and H. Sasaki, Wood Research, 68, 22 (1982).

8) 林 知行, 佐々木光, 冬木敏夫, 木材学会誌, 29, 663 (1983)。

9) 林知行, 佐々木光, 木材学会誌, 30, 23 (1984)。

10) M. Tokuda, M. Gakkaishi, 30, 139 (1984).

11）神谷文夫, 河合 誠, 畑山戥男, 岡田圭一郎, 木材学会 誌, 34, 326 (1988).

12）神谷文夫, 河合 誠, 畑山䧧男, 岡田圭一郎, 木材学会 誌, 34, 682 (1988).

13) 林 知行, 原田真樹, 海本一, 木材工業, 47, 120 (1992).

14) Y. Sasaki and H. Fumoto, Mokuzai Gakkaishi, 39, 636 (1993).

15）佐々木康寿，小笠原隆，三浦伸二，麓 秀彦，木材工業， 50, 314 (1995)

16) 井上正文, 清水 武, 沖林 聡, 田中圭, 後藤泰男, 構造上学論文集，45B，463（1999）。

17）日本建築学会編, “木質構造設計基準・同解説”, p.231, p.284（1995）日本建築学会.

18) Truss Plate Institute,"National Design Standard for Metal Plate Connected Wood Truss Construction”, p.2 (1995). 